\title{
Mode I Fracture Toughness Test and Fractal Character of Fracture Trajectory of Red Sandstone under Real-Time High Temperature
}

\author{
Yang Zejin ${ }^{1,2}$ and Changsuo Zhang (D) $^{1}$ \\ ${ }^{1}$ College of Mining Engineering, Taiyuan University of Technology, Taiyuan, Shanxi, China \\ ${ }^{2}$ Taiyuan Design Research Institute for Coal Industry, Taiyuan, Shanxi, China
}

Correspondence should be addressed to Changsuo Zhang; zhangchangsuo@tyut.edu.cn

Received 10 May 2019; Revised 2 August 2019; Accepted 14 August 2019; Published 13 October 2019

Guest Editor: Grzegorz Lesiuk

Copyright (C) 2019 Yang Zejin and Changsuo Zhang. This is an open access article distributed under the Creative Commons Attribution License, which permits unrestricted use, distribution, and reproduction in any medium, provided the original work is properly cited.

\begin{abstract}
To evaluate the stability and compactness of high-temperature underground construction, it is necessary to test the fracture toughness of surrounding rock (red sandstone) under real-time high temperature. In this paper, SCB specimens recommended by the International Society for Rock Mechanics are used to measure the mode I fracture toughness of red sandstone at real-time high temperatures. Also, to reveal its fracture characteristics and fracture mechanism, the fracture morphology observation (SEM experiment), XRD experiment, mercury intrusion porosimetry testing, and fractal measurement of fracture trajectory are carried out on the red sandstone specimens at various temperatures. The results show that (1) temperature may have a significant impact on the fracture toughness and fracture characteristics of red sandstone. On the whole, the fracture toughness values decrease with the increase in temperature, while the fractal dimensions of fractal trajectories increase with the increase in temperature. (2) Temperature has a significant influence on the fracture mode of red sandstone. At relatively low temperatures $\left(20^{\circ} \mathrm{C}-400^{\circ} \mathrm{C}\right)$, the main fracture mode is transgranular failure. At relatively high temperatures $\left(400^{\circ} \mathrm{C}-700^{\circ} \mathrm{C}\right)$, the fracture mode is mainly intergranular failure. (3) The weakening mechanism of red sandstone is mainly due to the effect of thermal dehydration when the temperature is between $100^{\circ} \mathrm{C}$ and $400^{\circ} \mathrm{C}$. When the temperature is between $400^{\circ} \mathrm{C}$ and $700^{\circ} \mathrm{C}$, the weakening mechanism is mainly due to thermal cracking and the $\alpha-\beta$ phase transition of quartz.
\end{abstract}

\section{Introduction}

In the deep geological disposal of high-level radioactive waste such as nuclear waste, the design requirements of surrounding rock and artificial barrier system are very strict. It is necessary to consider the original strength of surrounding rock as well as the influence of thermal stress on its microstructures. According to the study of Zuo et al. [1-4], the highest temperature in the surrounding rock will reach about $100^{\circ} \mathrm{C}-1000^{\circ} \mathrm{C}$ during the geological disposal of nuclear waste, which will make the surrounding rock undergo drastic high-temperature physical and chemical changes. To prevent the leakage of nuclear wastes, it is essential to study the evolutional processes of mechanical strength and internal microstructures of surrounding rock at high temperature in real time. Besides, in the fields of geothermal resource development, oil and gas and coalbed methane development, oil and gas geological storage, deep underground space utilization, and marine deep well drilling [5-8], it is also necessary to study the variational trend of physical and mechanical parameters of rock at high temperature and its weakening mechanism.

In geotechnical engineering science, fracture toughness is a property which describes the ability of a rock to resist fracture and is one of the most important features of any solid material for many underground tunnel design applications [9-12]. The linear-elastic fracture toughness of rock is determined from the stress intensity factor $(K)$ at which a thin crack in the material begins to grow and is a measurement of the energy required to produce a tiny crack. Proverbially, the fracture behavior of rock strata will be significantly affected by geostatic stress and thermal stress. And, it has been widely proved that many initial 
cracks and microcracks induced by external stress disturbance (i.e., excavation-induced cracks and fissures) are widely and randomly distributed in surrounding rock. Thus, under the action of in situ stress and thermal stress, when the stress intensity factor at the crack tip is higher than the fracture toughness of surrounding rock, microcracks in surrounding rock will further expand, propagate, and coalesce and eventually form macroscopic cracks, which will ultimately affect the stability and safety of underground engineering buildings. Therefore, to accurately evaluate the stability and safety of underground engineering, it is necessary to conduct experimental research on the fracture behavior of rock and the corresponding crack growth law.

It should be noted that, for some complex underground and tunneling projects, surrounding rock is often greatly affected by extremely high temperature. For examples, when the radioactive nuclear waste is deeply buried, a large amount of heat will be generated due to the decay of radioactive elements (137Cs, $60 \mathrm{Co}, 90 \mathrm{Sr}$, etc.) [13]. Usually, these heats will cause the temperature of the surrounding rock to be as high as $1000^{\circ} \mathrm{C}$. However, the existing studies show that local thermal stress will be generated between mineral particles due to the differences in the thermal expansion coefficient between rock mineral particles at high temperature. In this way, the internal structure of the particles will change substantially, and thermal cracking may occur in the rock, which eventually affects the physical and mechanical properties of the rock [14-19]. Besides, it is also well known that the fracture trajectories and fracture roughness and surface morphology are strictly related to the seepage behavior of geofluids. Therefore, the fracture toughness and fracture characteristics of surrounding rock at real-time high temperature need to be studied to evaluate the migration paths of geological storage of nuclear wastes.

As a typical sedimentary rock, sandstones are widely distributed in nature. Due to the influence of the geochemical environment, there are substantial differences in mineral composition, particle shape, and cement type. After treatment with high temperature, the minerals in the sandstone undergo a polycrystalline transformation, and their mineral composition and physical and mechanical parameters will correspondingly change. Previously, several scholars have concentrated on the study of the damage mechanism, failure criterion, microstructure, and texture evolution of rocks after treatment with high temperature and have obtained some useful research results. Zuo et al. [1-4] systematically studied the thermal cracking, failure mechanism, and fracture morphology of sandstone at various temperatures in real time and determined the influence of temperature on the fracture behavior of sandstone; that is, with the increase in temperature, the fracture mode of rock changes from local brittle fracture to local brittle-ductile coupling fracture. And they considered that $300^{\circ} \mathrm{C}$ is the threshold temperature for the brittleductile transition. In the transition zone, the fracture morphologies of rocks are more diverse and complex. Mahanta et al. [9] have carried out the model I fracture toughness tests of Manoharpur sandstone of India after high-temperature treatment. The results show that the fracture toughness of sandstone reaches its maximum when the temperature reaches $100^{\circ} \mathrm{C}$. Then, the value decreases sharply with the increase in temperature. Feng et al. $[20,21]$ studied the effect of temperature on the mode I fracture toughness and fracture characteristics of Chinese sandstone. The results show that the change rate of fracture toughness of sandstone is closely related to temperature. Tian et al. [22] studied the variational trend of physical properties of sandstone subjected to high temperature. It is found that the permeability increased gradually with the increase in temperature. The bulk density of sandstone decreased significantly at a temperature above $500^{\circ} \mathrm{C}$, and the porosity increased substantially at a temperature above $300^{\circ} \mathrm{C}$. Johnson et al. studied the change characteristics of wave velocity of granite, limestone, diabase, and sandstone after treatment with high temperature. It is found that the wave velocity will attenuate at high temperature, and the phenomenon is closely related to grain boundary cracking.

In summary, under the action of high temperature, the minerals in sandstone will undergo physical and chemical changes such as dehydration, melting, decomposition, and phase transformation, which will lead to great changes in the crystal structure and composition of minerals. However, the above scholars have not revealed the thermal damage mechanism of rocks from the mineralogical direction, and the correlation between micro- and macromechanical parameters has not been discussed. Although the relevant scholars have qualitatively analyzed the changes of chemical and mineral composition using XRD and FT-Raman spectroscopy, a great number of research works still need to be done on the quantitative analysis of compositional variation in minerals, the relationship between the evolution process of mineral components and physical and variational trend of mechanical parameters, microfracture morphology, porosity, and other micro-macroparameters. Given the complicated temperature-related engineering problems, the fracture toughness and fracture characteristics of typical red sandstone at real-time high temperature are carried out in this paper. Besides, microscopic analysis such as quantitative XRD analysis (mineral composition), SEM fractographic analysis (fracture topography), mercury intrusion porosimetry measurement, and fractal measurement (fracture propagation trajectory) reveal the thermal fracture mechanism of sandstone and the correlations of micro-macromechanical parameters.

\section{Materials and Methods}

2.1. SCB Specimens and Calculation of Mode I Fracture Toughness. In fracture mechanics, there are three types of fracture: mode I (tensile fracture), mode II (shear fracture), and mode III (out-of-plane tearing fracture) [20-29]. Among them, mode I fracture is the most frequently encountered in underground geotechnical engineering [20,30,31]. Several tests have been proposed to estimate the mode I fracture toughness of rocks, namely, the chevron bend (CB) test 
[32, 33], the edge cracked circular specimen subjected to wedge loading [34], the center-cracked ring specimen subjected to diametral compression [35], the single-edge-cracked round bar in the bending test [36], noncircular shape specimens such as the edge-cracked rectangular beam specimen subjected to three- or four-point bending [37,38], the short rod (SR) test $[38,39]$, the central straight through the Brazilian disk test [33], the cracked chevron-notched Brazilian disk (CCNBD) test [40, 41], the SCB test, and the straightnotched disk bending test [42], and edge crack triangular (ECT) specimen [43]. The International Society for Rock Mechanics (ISRM) [42-44] suggested CB, SR, and CCNBD tests for the determination of the static fracture toughness of rocks. The SCB test was added to the suggested methods in 2014 [45]. In this paper, the SCB test was chosen to estimate the fracture toughness of the rocks for its simplicity of specimen preparation, equipment, and testing procedure [46] (Figures 1 and 2).

The data obtained from the experiment are calculated and processed according to the ISRM recommended method. Fracture toughness $K_{I C}$ of SCB specimens is calculated from the following formula [45]:

$$
\begin{aligned}
K_{\mathrm{IC}}= & \frac{P_{\max } \sqrt{\pi \alpha}}{2 \mathrm{RB}} Y^{*}, \\
Y^{*}= & -1.297+9.516\left[\frac{S}{(2 R)}\right] \\
& -\left\{0.47+16.457 \cdot\left[\frac{S}{(2 R)}\right]\right\} \beta \\
& +\left\{1.071+34.401\left[\frac{S}{(2 R)}\right]\right\} \beta^{2}, \\
\beta= & \frac{a}{R},
\end{aligned}
$$

where $P_{\max }$ is the peak load and $Y^{*}$ is the dimensionless stress intensity factor.

The geometric dimensioning of SCB specimens used in this paper is as follows: $B=20 \mathrm{~mm} ; a=12.5 \mathrm{~mm} ; R=25 \mathrm{~mm}$; $\mathrm{S} /(2 \mathrm{R})=0.61 ; a / R=0.5 ; Y^{*}=4.7672775[45]$.

2.2. Sample Preparation. Red sandstones are taken from the Taiyuan area, Shanxi Province. The main components of sandstone are albite and quartz. The specimens are light red and cemented with shale. The particle size is $0.1-0.7 \mathrm{~mm}$, and the average particle size is about $0.4 \mathrm{~mm}$ (see Table 1 for detailed composition and content). The sandstone has a density of $1.93 \mathrm{~g} / \mathrm{cm}^{3}$, a porosity of $7.16 \%$, a uniaxial compressive strength of $37.6 \mathrm{MPa}$, a uniaxial tensile strength of 3.4 MPa, a $P$ wave velocity of $1982 \mathrm{~m} / \mathrm{s}$, and a $S$ wave velocity of $1269 \mathrm{~m} / \mathrm{s}$. parts:

The sample preparation process can be divided into three

(1) Place the sandstone on a flat platform. When the fixing is completed, the cylindrical cores are drilled at a speed of $10 \mathrm{~mm} / \mathrm{s}$ using a drill with a diameter of $50 \mathrm{~mm}$.

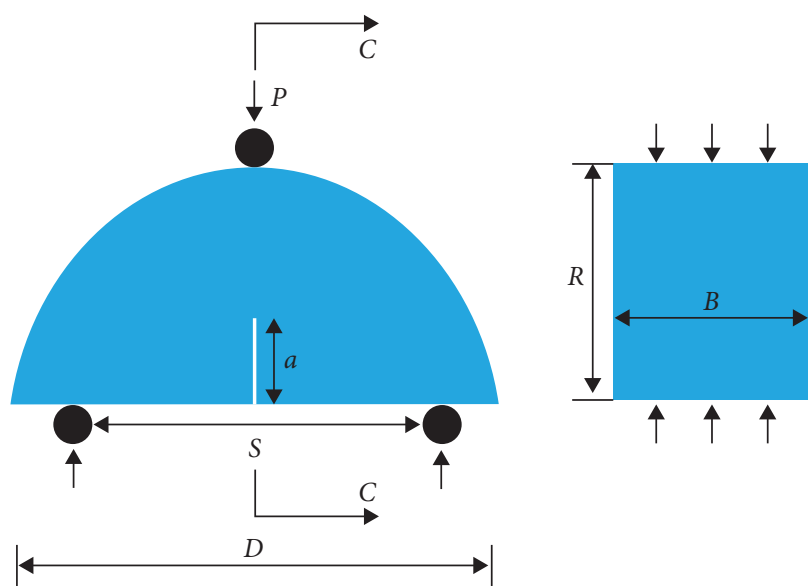

Figure 1: SCB specimen geometry. $R$, sample radius; $B$, sample thickness; $a$, precrack length; $S$, support span; $P$, load.

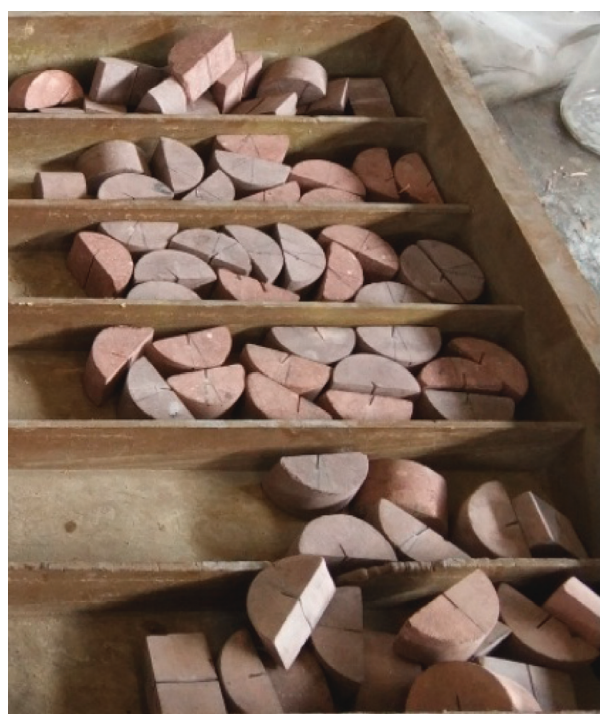

FIgURE 2: The SCB specimens.

(2) The cores obtained are cut into the semidisc samples with a thickness of $25 \mathrm{~mm}$ by a cutter. Then, the ends of the tested samples are smoothed using 30 -grit fine sandpaper.

(3) Clamp the semicircular specimen with pliers. After the fixing is completed, the crack prefabrication is performed on the tested samples by using the crack prefabrication equipment. The thickness of the saw blade in the crack prefabrication equipment is $0.4 \mathrm{~mm}$.

\section{Experimental Results}

3.1. Load-Displacement Curves. During the thermomechanical loading, the experimental load-displacement curves were recorded automatically. By analyzing the experimental load-displacement curves, the fracture in compression is a complex process consisting of 4 stages of fracture development (as shown in Figure 3). (1) Compaction stage (OA): 
TABle 1: Compositions and contents of the tested specimens (mean value).

\begin{tabular}{lcccc}
\hline Chemical component & Quartz $\left(\mathrm{SiO}_{2}\right)$ & Albite $\left(\mathrm{Ca}-\right.$ rich $\left.\left((\mathrm{Na}, \mathrm{Ca}) \mathrm{Al}(\mathrm{Si}, \mathrm{Al})_{3} \mathrm{O}_{8}\right)\right)$ & Albite $\left(\mathrm{NaAlSi}_{3} \mathrm{O}_{8}\right)$ & $\mathrm{Anorthite}\left(\mathrm{CaAl}_{2} \mathrm{Si}_{2} \mathrm{O}_{8}\right)$ \\
\hline Content & $85.4 \%$ & $8.7 \%$ & $4.8 \%$ & $1.1 \%$ \\
\hline
\end{tabular}

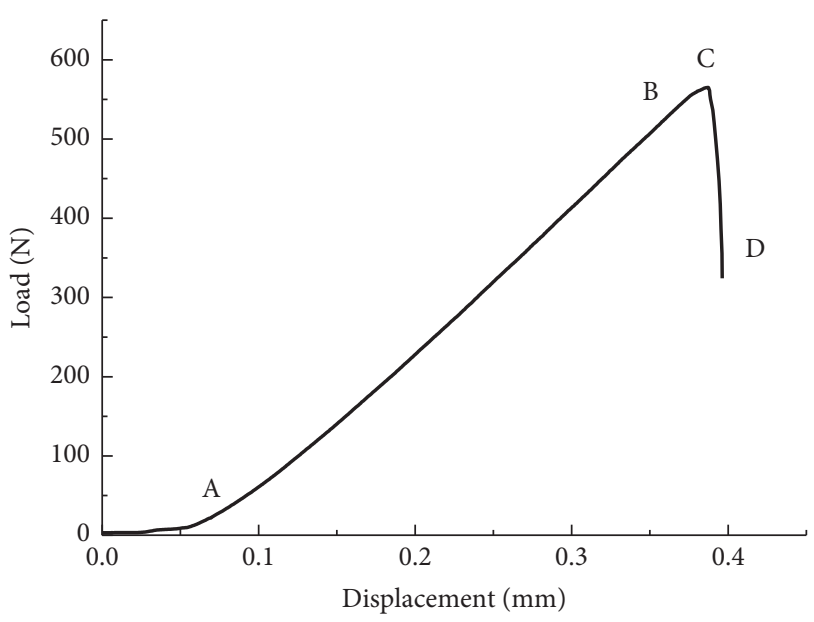

Figure 3: Typical load-displacement curve of sandstone.

the curve bends slightly upward, which is caused by the closure of origin cracks. (2) Elastic stage (AB): at this stage, the shape of the curve is close to a straight line. This is because the axial force is linear with the displacement. (3) Plastic deformation stage (BC), sandstone: at this stage, the force-displacement curves bend downward; that is, the processes exhibit stronger nonlinear trends in the relationship between force and displacement. Besides, the slope of the force-displacement curve gradually decreases to zero as the force increases. (4) Complete failure stage (CD): the force drops sharply. At this point, the load reaches its peak, which means that the rock has been completely broken into small pieces.

Since the force-displacement curves of sandstone specimens at the identical temperature have similar variational trend, the typical force-displacement curves of each condition are listed in this paper, as shown in Figure 4. From the forcedisplacement curves of sandstone at various temperatures, it can be concluded that (1) the variational trend of complete force-displacement curves of sandstone is all the same, which has been divided into compaction stage, elastic-plastic deformation stage, and failure stage; (2) at room temperature $\left(20^{\circ} \mathrm{C}\right)$, sandstone suddenly breaks after the plastic stage, indicating a typical brittle failure; (3) when the temperature rises to $100^{\circ} \mathrm{C}-400^{\circ} \mathrm{C}$, the curve slope at the elastic stage (AB) changes obviously; that is, the slope decreases gradually with the increase in temperature. In addition, the phenomenon of "load drop" appears on the curve. The main reason for this change is that sandstone produces a series of complex microcracks under the action of high temperature. When the microcracks expand and evolve through each other during loading, the load will drop suddenly; (4) when the temperature rises to $400^{\circ} \mathrm{C}-600^{\circ} \mathrm{C}$, the prepeak $\mathrm{AC}$ and $\mathrm{CD}$ sections of the load-displacement curve tend to be gentle gradually, and the maximum displacement will also show an increasing

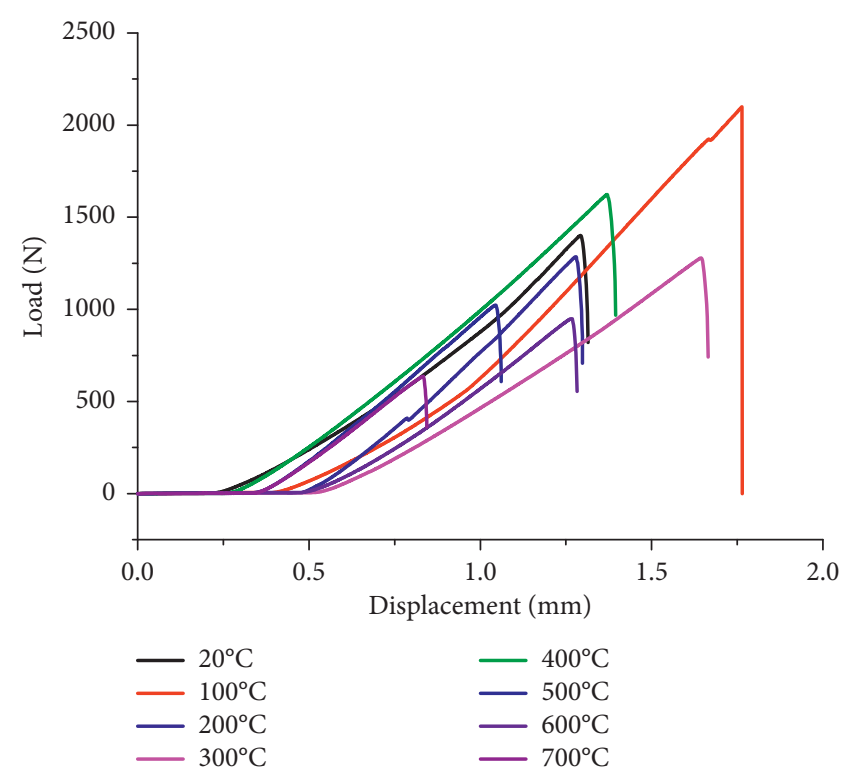

FIgURE 4: Typical load-displacement curve of sandstone at various temperatures.

trend with the increase in temperature. This is mainly due to the decrease in brittleness index and the enhancement of ductility of the specimens.

At real-time high temperature, the relationships between the mean of fracture toughness of sandstone specimens and temperature are shown in Figure 5 and Table 2. On the whole, the fracture toughness of sandstone at different temperatures has a certain degree of discreteness, which is mainly due to the structural differences of sandstone. The variational trend of fracture toughness of sandstone with temperature has the following characteristics: (1) with the increase in temperature, the value of fracture toughness of sandstone first increases then decreases; the value of fracture toughness reaches the maximum at $100^{\circ} \mathrm{C}$, which is $4.27 \mathrm{MPa} \mathrm{m}^{0.5}$, and the value is $0.18 \mathrm{MPa} \mathrm{m}^{0.5}$ when the temperature rises to $700^{\circ} \mathrm{C}$, which is $95.7 \%$ lower than that at $100^{\circ} \mathrm{C}$. This fully demonstrates that the fracture behaviors of sandstone are greatly affected by high temperature. (2) According to the relationships between fracture toughness and temperature (i.e., curve slope), the variational trend of the curve can be divided into three stages: (1) the slow increase stage $\left(20^{\circ} \mathrm{C}-100^{\circ} \mathrm{C}\right)$. The curve slope at this stage is 0.0055. (2) The slow descent stage $\left(100^{\circ} \mathrm{C}-400^{\circ} \mathrm{C}\right)$. The curve slope at this stage is 0.0048 . (3) The rapid descending stage $\left(400^{\circ} \mathrm{C}-700^{\circ} \mathrm{C}\right)$, in which the slope of the curve is 0.0087 . Based on these, it seems that the brittle-ductile transition of sandstone occurs at $400^{\circ} \mathrm{C}$.

3.2. Fracture Trajectory. It is well known that the shape and trajectory of rock fracture are determined by its 


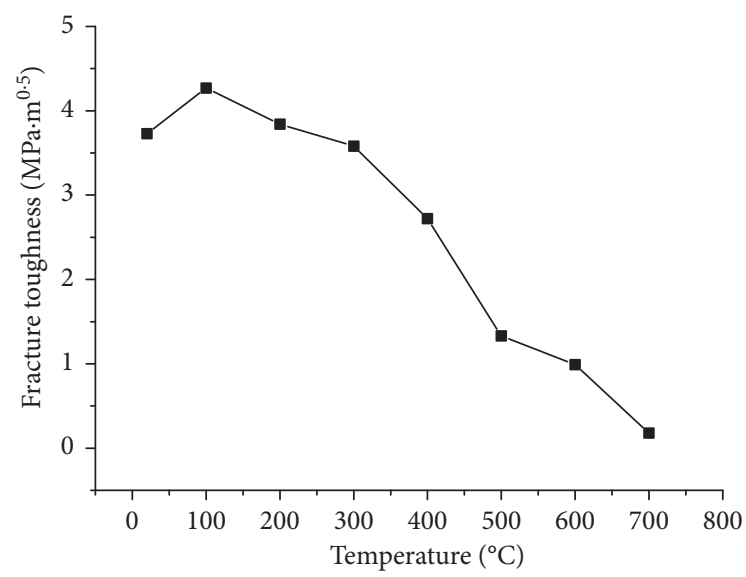

Figure 5: The relationship between temperature and the mean of fracture toughness.

TABLE 2: Fracture toughness values of sandstone at various temperatures.

\begin{tabular}{lcccccccc}
\hline Temperature $\left({ }^{\circ} \mathrm{C}\right)$ & $\# 1$ & $\# 2$ & $\# 3$ & $\# 4$ & $\# 5$ & $\# 6$ & Mean & Standard deviation \\
\hline 20 & 4.05 & 3.42 & 4.08 & 3.62 & 3.91 & 3.29 & 3.73 & 0.34 \\
100 & 4.19 & 4.46 & 4.69 & 4.17 & 4.08 & 4.06 & 4.27 & 0.25 \\
200 & 4.05 & 4.09 & 3.46 & 3.97 & 3.69 & 3.80 & 3.84 & 0.24 \\
300 & 3.40 & 3.30 & 3.90 & 3.28 & 3.87 & 3.72 & 3.58 & 0.28 \\
400 & 2.78 & 3.08 & 2.49 & 3.21 & 2.20 & 2.57 & 2.72 & 0.38 \\
500 & 1.57 & 1.29 & 1.35 & 1.41 & 1.15 & 1.19 & 1.33 & 0.16 \\
600 & 0.81 & 1.25 & 0.89 & 1.02 & 1.18 & 0.80 & 0.99 & 0.18 \\
700 & 0.15 & 0.12 & 0.17 & 0.26 & 0.14 & 0.25 & 0.06 & 0.19 \\
\hline
\end{tabular}

microfracture mechanism, which can directly reflect the macrofracture characteristics of the rock. Since the initiation cracks generally occur at the surface, subsurface, stress concentration zones, and internal defects of the specimen, the fracture propagation path of the specimen is tortuous and continuously changing. According to the previous studies, it is widely recognized that fracture modes can be classified into 3 categories: transgranular fracture, intergranular fracture, and mixed fracture, which can be presented on the surface of the specimen. According to the research results of Zuo et al. [1-4], it can be concluded that the roughness of the fracture surface after fracture is a comprehensive reflection of its microstructure, a magnitude of load and temperature [47, 48]. Therefore, the fracture trajectory is closely related to the roughness of the rock mass structural surface [49-53]. According to the research results of Liu et al. [53], the roughness of the structural plane can directly affect the shear strength and permeability of surrounding rock, whereas the shear strength and permeability are closely related to the stability and compactness of nuclear waste storage. Therefore, in this section, to quantitatively evaluate the tortuosity and complexity of fracture trajectory, the fractal theory and box counting method are used to describe the change law of fracture trajectories and quantitatively obtain the relationship between the tortuosity of fracture propagation path and temperature of sandstone (Figure 6).

The average of fracture deviations from the center line originating at the notch tip of sandstone specimens at the temperature ranging from room temperature $\left(20^{\circ} \mathrm{C}\right)$ to

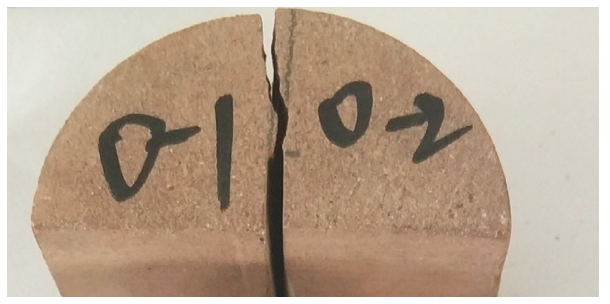

Figure 6: Fracture trajectory of red sandstone at $700^{\circ} \mathrm{C}$.

$700^{\circ} \mathrm{C}$ is shown in Figure 7 and Table 3 . It can be clearly obtained that the value gradually increases with the increase in temperature. And, it is smaller at relatively low temperatures $\left(20^{\circ} \mathrm{C}-400^{\circ} \mathrm{C}\right)$ but larger at relatively high temperatures $\left(400^{\circ} \mathrm{C}-700^{\circ} \mathrm{C}\right)$. This is because sandstone belongs to a kind of brittle material at a relatively low temperature. According to the theory of energy dissipation, when the brittleness coefficient of the specimen is higher, it is easier to be entirely destroyed, which is mainly manifested by dynamic instability behavior such as the violent spattering of broken rock blocks. Regarding this kind of fracture mode, transgranular failure is more likely to occur so that the fracture deviation is smaller. When the temperature increases, the fracture mode of the specimen gradually transforms from brittleness to ductility. Hence, the postpeak deformation of the specimen becomes more substantial, and the elastic release energy of the specimen decreases. Under this condition, the intergranular failure is more prone to occur to the specimen. In addition, due to thermal cracking, 


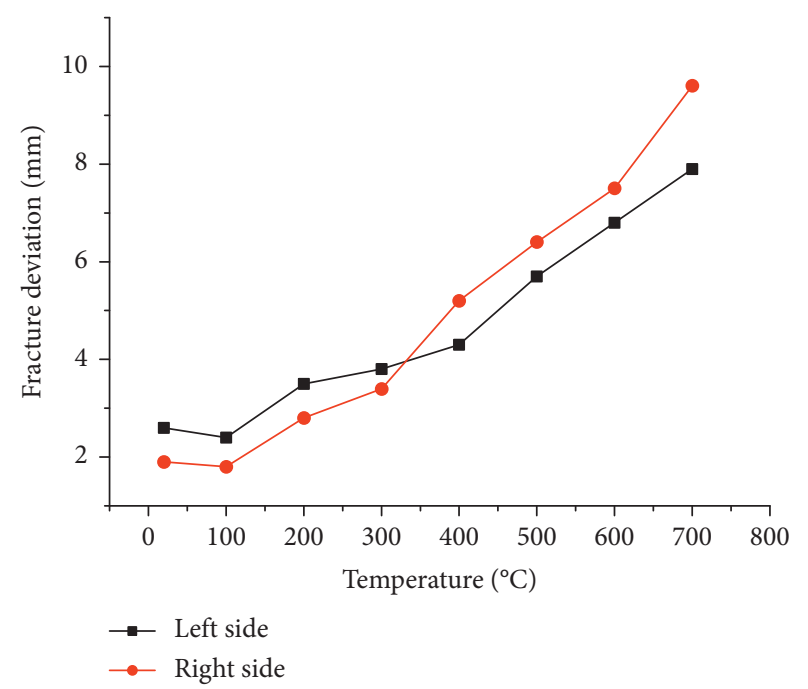

FIgURE 7: The average of fracture deviation of sandstone at different temperatures.

TABLE 3: The average of fracture deviation from center line of sandstone at various temperatures.

\begin{tabular}{lcc}
\hline Temperature $\left({ }^{\circ} \mathrm{C}\right)$ & $\begin{array}{c}\text { Fracture deviation } \\
\text { (left side) }(\mathrm{mm})\end{array}$ & $\begin{array}{c}\text { Fracture deviation } \\
\text { (right side) }(\mathrm{mm})\end{array}$ \\
\hline 20 & 2.6 & 1.9 \\
100 & 2.4 & 1.8 \\
200 & 3.5 & 2.8 \\
300 & 3.8 & 4.5 \\
400 & 4.3 & 5.2 \\
500 & 5.7 & 6.4 \\
600 & 6.8 & 7.5 \\
700 & 7.9 & 9.6 \\
\hline
\end{tabular}

a serious of complex microcracks, fissures, and voids are randomly generated in the specimen, which will make the crack propagation path be extremely irregular. Therefore, under high-temperature conditions, due to the change of fracture mode and thermal cracking, a large fracture deviation is formed.

According to the previous studies, the fracture trajectories of the specimens obviously have strong statistical selfaffinity. Hence, the fracture propagation path on the sandstone surface can be described by fractal dimension [18-20]. By performing binarization on the crack images, black-and-white bitmaps of simple cracks are obtained. Then, the black-and-white bitmaps of the crack are covered by the boxes. Since the total number of boxes varies with the size $W$, the cracks with different shapes and sizes will correspond to the different data sets $(W, N)$. When logarithms of $1 / W$ and $N$ are taken, respectively, a new set of data $(\ln (1 / W), \ln N)$ is obtained. Then, these data are plotted into a logarithmic graph, and a set of equation is obtained after linear regression analysis, as shown in equation (3):

$$
\ln N=a+D \ln \left(\frac{1}{W}\right)
$$

where $D$ is the slope of the regression line, and it is also the fractal dimension of the fracture propagation path.
Note that we register exactly the same trajectory of a specimen for three times and we calculate the fractal dimensions immediately. Note that six SCB specimens were used for exploring the fracture characteristics under each set of temperature. Therefore, 18 tests (the calculation of fractal dimension of fracture trajectories) were performed in total under each set of temperature. The average fractal dimensions and total errors of fracture trajectories at each temperature are shown in Table 4. From the experimental results (see Figure 8 and Table 4), we can obtain that the fracture trajectory of specimen has strong irregularity and fractality. With the increase in temperature, the average fractal dimension value increases gradually. For example, when the experimental temperature is $20^{\circ} \mathrm{C}$, the average fractal dimension is $1.19 \pm 0.03$, and when the temperature is raised to $700^{\circ} \mathrm{C}$, the average fractal dimension is increased to $1.84 \pm 0.06$, which is $52.1 \%$ higher than the room temperature. This fully demonstrates that the fracture trajectory of the sandstone samples becomes more and more complicated and tortuous.

\section{Discussion}

4.1. Correlation of Micro-Macromechanical Parameters. The main mineral components of sandstone are quartz and albite. After treatment with high temperature, the pore structure, surface morphology, crystal structure, and mineral composition of the specimens have undergone a series of complex changes. This will strongly influence the fracture behavior of sandstone. As shown in Table 5, the diffraction peaks of quartz and feldspar change obviously after treatment with a high temperature of $200^{\circ} \mathrm{C}$. Compared with room temperature and $100^{\circ} \mathrm{C}$, the content of quartz decreases, while feldspar increases. When the temperature is raised to $300^{\circ} \mathrm{C}$, the quartz content in the sample is further reduced, and the feldspar content is also significantly reduced. Among them, the content of calcium-rich albite and calciferous feldspar increases compared with that at $200^{\circ} \mathrm{C}$. In addition, it is interesting to find that a new mineral component, laumontite, appears in the samples. This is because the sodium feldspar in the sample undergoes a dehydration reaction at a high temperature, and the decomposition product chemically reacts with quartz to form the new mineral. When the temperature is between $400^{\circ} \mathrm{C}$ and $700^{\circ} \mathrm{C}$, the laumontite disappears, and new minerals (i.e., calcium feldspar rich in sodium) appear in the sample. And the quartz content is gradually increased at this stage as the temperature increases.

It is worthy to note that chemical reactions between mineral particles (crystalline water removal, the formation of new materials, decomposition reaction, and lattice transformation) will lead to a series of physical changes, such as the increase in pore structure, the generation of new pore and fracture, and volume expansion. According to the experimental results, we can conclude that the higher the temperature is, the more complex the chemical reactions occur in the crystals of sandstone. For example, when the temperature of sandstone rises from room temperature to $700^{\circ} \mathrm{C}$, quartz decomposition and synthesis, the transformation between 
TABLE 4: Average fractal dimension values of crack development paths under different temperatures.

\begin{tabular}{lcc}
\hline Temperature $\left({ }^{\circ} \mathrm{C}\right)$ & Average fractal dimension $(D)$ & Total error \\
\hline 20 & 1.19 & 0.03 \\
100 & 1.12 & 0.07 \\
200 & 1.26 & 0.04 \\
300 & 1.32 & 0.04 \\
400 & 1.39 & 0.02 \\
500 & 1.43 & 0.09 \\
600 & 1.68 & 0.11 \\
700 & 1.84 & 0.06 \\
\hline
\end{tabular}

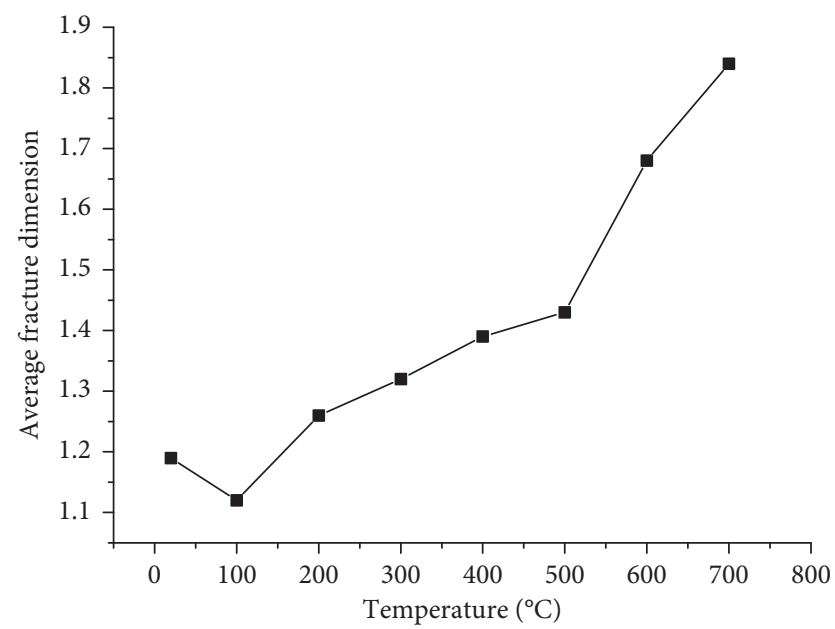

FIgURE 8: The relationship between average fractal dimension and temperature.

quartz crystals, dehydration of feldspar, and synthesis and decomposition of feldspar will occur. Because the heating rate in this paper is relatively low, it means that the chemical reactions experienced by mineral crystals at $700^{\circ} \mathrm{C}$ include not only all chemical reactions from room temperature to $600^{\circ} \mathrm{C}$, but also those occurring at $700^{\circ} \mathrm{C}$. But for $200^{\circ} \mathrm{C}$, only a small part of quartz and feldspar is decomposed or synthesized. Therefore, the macroparameter (i.e., fracture toughness) gradually decreases with the increase in temperature.

However, to accurately determine the relationship between the macro- and microparameters of the sample, the $\mathrm{XRD}$ experiment is obviously not enough. Because the analysis of mineral composition or XRD experimental study only shows the variation of parameters concerning temperature from a qualitative point of view, which does not quantitatively reflect the correlation between macroparameters and microparameters. To quantitatively explain the variation of fracture toughness of sandstone concerning temperature, mercury injection experiments are also needed for sandstone.

The variation of average pore size and porosity of sandstone with respect to temperature is shown in Table 6 and Figure 9. According to the experimental results, it is implied that the pore structures gradually transit from dense to porous and fluffy. For example, when the temperature is $100^{\circ} \mathrm{C}$, the average pore size and porosity of sandstone slightly decrease compared with that at $20^{\circ} \mathrm{C}$. When the temperature is between $100^{\circ} \mathrm{C}$ and $700^{\circ} \mathrm{C}$, these parameters of sandstone gradually increase with the increase in temperature, which indicates that the micropores in sandstone gradually change to mesopores and macropores. On the whole, the variation of these parameters with respect to temperature can be divided into three stages: slow increase stage $\left(20^{\circ} \mathrm{C}-100^{\circ} \mathrm{C}\right)$, slow decline stage $\left(100^{\circ} \mathrm{C}-400^{\circ} \mathrm{C}\right)$, and sharp decline stage $\left(400^{\circ} \mathrm{C}-700^{\circ} \mathrm{C}\right)$. Besides, it should be pointed out that the variational trend of microparameters is basically consistent with that of macroparameters (i.e., fracture toughness), which give strong support to the correlation of macroscopic and microscopic parameters.

4.2. Correlation of Micro-Macrofracture Mode. Based on the load-displacement curves, it can be obtained that when the temperature is between $20^{\circ} \mathrm{C}$ and $400^{\circ} \mathrm{C}$, the fracture mode of the sandstone is mainly characterized by brittle fracture. When the temperature is between $400^{\circ} \mathrm{C}$ and $700^{\circ} \mathrm{C}$, the fracture mode of the sandstone begins to show some ductility. The macroscopic fracture mode and fracture trajectory of the rock are fundamentally determined by the microscopic fracture mechanism. Therefore, the SEM observation of the fracture surface is necessary.

On the whole, the fracture mode of the specimen at a relatively low temperature $\left(20^{\circ} \mathrm{C}-400^{\circ} \mathrm{C}\right)$ is mainly characterized by transgranular fracture. With the increase in temperature, the mineral particles gradually become loose, and the opening degree of the interfaces between the crystals gradually becomes more considerable. Moreover, due to the influence of thermal stress and expansion force, a series of complicated cracks are randomly distributed in the samples. As a result, the fracture mode of specimens become more complex and diversified. The fracture mode of the specimen at this temperature stage $\left(400^{\circ} \mathrm{C}-700^{\circ} \mathrm{C}\right)$ is mainly characterized by intergranular fracture. This is also consistent with previous scholars' research results. It is worth noting that cracks tend to propagate and evolve along with the interface of crystals under these conditions. Besides, the fractures will also coalesce with the thermal cracks under loading. Hence, the roughness of the fracture surface at high temperature is more significant than that at low temperature. Therefore, the fracture trajectory of the sample becomes more tortuous, and the fractal dimension gradually increases.

Interestingly, however, there are some differences in the fracture morphology of the specimens at real-time high temperatures, which have not been found in the specimens after treatment with high temperatures (the results of Feng et al. [17]); that is, some cracks appear on the fracture surface at $400^{\circ} \mathrm{C}$ and the density, number, and aperture of the fractures increase with the increasing temperature, as shown in Figure 10. This is because some of the crystals in the specimens are molten under real-time high-temperature conditions, and the fracture behaviors are similar to those of soft rock, so the sandstone tends to deform plastically. Plastic deformation can cause tearing cracks in the fracture surfaces of a specimen. 
TABLE 5: The mineral composition and mass content of sandstone at various temperatures.

\begin{tabular}{|c|c|c|c|}
\hline Temperature $\left({ }^{\circ} \mathrm{C}\right)$ & Mineral composition & Chemical formula & Mass content (\%) \\
\hline 25 & $\begin{array}{c}\text { Quartz } \\
\text { Albite, Ca-rich } \\
\text { Albite } \\
\text { Anorthite } \\
\end{array}$ & $\begin{array}{c}\mathrm{SiO}_{2} \\
(\mathrm{Na}, \mathrm{Ca}) \mathrm{Al}(\mathrm{Si}, \mathrm{Al})_{3} \mathrm{O}_{8} \\
\mathrm{NaAlSi}_{3} \mathrm{O}_{8} \\
\mathrm{CaAl}_{2} \mathrm{Si}_{2} \mathrm{O}_{8} \\
\end{array}$ & $\begin{array}{c}67 \\
9 \\
21 \\
3\end{array}$ \\
\hline 100 & $\begin{array}{c}\text { Quartz } \\
\text { Albite, Ca-rich } \\
\text { Albite } \\
\text { Anorthite } \\
\end{array}$ & $\begin{array}{c}\mathrm{SiO}_{2} \\
(\mathrm{Na}, \mathrm{Ca}) \mathrm{Al}(\mathrm{Si}, \mathrm{Al})_{3} \mathrm{O}_{8} \\
\mathrm{NaAlSi}{ }_{3} \mathrm{O}_{8} \\
\mathrm{CaAl}_{2} \mathrm{Si}_{2} \mathrm{O}_{8} \\
\end{array}$ & $\begin{array}{c}67 \\
9 \\
21 \\
3 \\
\end{array}$ \\
\hline 200 & $\begin{array}{c}\text { Quartz } \\
\text { Albite, Ca-rich } \\
\text { Albite } \\
\text { Anorthite } \\
\end{array}$ & $\begin{array}{c}\mathrm{SiO}_{2} \\
(\mathrm{Na}, \mathrm{Ca}) \mathrm{Al}(\mathrm{Si}, \mathrm{Al})_{3} \mathrm{O}_{8} \\
\mathrm{NaAlSi}_{3} \mathrm{O}_{8} \\
\mathrm{CaAl}_{2} \mathrm{Si}_{2} \mathrm{O}_{8} \\
\end{array}$ & $\begin{array}{c}52 \\
14 \\
29 \\
5\end{array}$ \\
\hline 300 & $\begin{array}{c}\text { Quartz } \\
\text { Albite, Ca-rich } \\
\text { Anorthite } \\
\text { Laumontite } \\
\end{array}$ & $\begin{array}{c}\mathrm{SiO}_{2} \\
(\mathrm{Na}, \mathrm{Ca}) \mathrm{Al}(\mathrm{Si}, \mathrm{Al})_{3} \mathrm{O}_{8} \\
\mathrm{CaAl}_{2} \mathrm{Si}_{2} \mathrm{O}_{8} \\
\mathrm{Ca}\left[\mathrm{AlSi}_{2} \mathrm{O}_{6}\right]_{2} * 4 \mathrm{H}_{2} \mathrm{O}\end{array}$ & $\begin{array}{c}47 \\
27 \\
19 \\
7 \\
\end{array}$ \\
\hline 400 & $\begin{array}{c}\text { Quartz } \\
\text { Albite, Ca-rich } \\
\text { Albite } \\
\text { Anorthite } \\
\text { Anorthite, Na-rich }\end{array}$ & $\begin{array}{c}\mathrm{SiO}_{2} \\
(\mathrm{Na}, \mathrm{Ca}) \mathrm{Al}(\mathrm{Si}, \mathrm{Al})_{3} \mathrm{O}_{8} \\
\mathrm{NaAlSi}_{3} \mathrm{O}_{8} \\
\mathrm{CaAl}_{2} \mathrm{Si}_{2} \mathrm{O}_{8} \\
(\mathrm{Ca}, \mathrm{Na})(\mathrm{Si}, \mathrm{Al})_{4} \mathrm{O}_{8}\end{array}$ & $\begin{array}{c}57 \\
23 \\
15 \\
3 \\
2 \\
\end{array}$ \\
\hline 500 & $\begin{array}{c}\text { Quartz } \\
\text { Albite, Ca-rich } \\
\text { Albite } \\
\text { Anorthite } \\
\text { Anorthite, Na-rich }\end{array}$ & $\begin{array}{c}\mathrm{SiO}_{2} \\
(\mathrm{Na}, \mathrm{Ca}) \mathrm{Al}(\mathrm{Si}, \mathrm{Al})_{3} \mathrm{O}_{8} \\
\mathrm{NaAlSi}_{3} \mathrm{O}_{8} \\
\mathrm{CaAl}_{2} \mathrm{Si}_{2} \mathrm{O}_{8} \\
(\mathrm{Ca}, \mathrm{Na})(\mathrm{Si}, \mathrm{Al})_{4} \mathrm{O}_{8}\end{array}$ & $\begin{array}{c}53 \\
11 \\
26 \\
6 \\
4\end{array}$ \\
\hline 600 & $\begin{array}{c}\text { Quartz } \\
\text { Albite, Ca-rich } \\
\text { Albite } \\
\text { Anorthite } \\
\text { Anorthite, Na-rich }\end{array}$ & $\begin{array}{c}\mathrm{SiO}_{2} \\
(\mathrm{Na}, \mathrm{Ca}) \mathrm{Al}(\mathrm{Si}, \mathrm{Al})_{3} \mathrm{O}_{8} \\
\mathrm{NaAlSi}_{3} \mathrm{O}_{8} \\
\mathrm{CaAl}_{2} \mathrm{Si}_{2} \mathrm{O}_{8} \\
(\mathrm{Ca}, \mathrm{Na})(\mathrm{Si}, \mathrm{Al})_{4} \mathrm{O}_{8}\end{array}$ & $\begin{array}{c}67 \\
9 \\
18 \\
4 \\
2 \\
\end{array}$ \\
\hline 700 & $\begin{array}{c}\text { Quartz } \\
\text { Albite, Ca-rich } \\
\text { Albite } \\
\text { Anorthite } \\
\text { Anorthite, Na-rich }\end{array}$ & $\begin{array}{c}\mathrm{SiO}_{2} \\
(\mathrm{Na}, \mathrm{Ca}) \mathrm{Al}(\mathrm{Si}, \mathrm{Al})_{3} \mathrm{O}_{8} \\
\mathrm{NaAlSi}_{3} \mathrm{O}_{8} \\
\mathrm{CaAl}_{2} \mathrm{Si}_{2} \mathrm{O}_{8} \\
(\mathrm{Ca}, \mathrm{Na})(\mathrm{Si}, \mathrm{Al})_{4} \mathrm{O}_{8}\end{array}$ & $\begin{array}{c}75 \\
6 \\
14 \\
3 \\
2 \\
\end{array}$ \\
\hline
\end{tabular}

TABLE 6: Pore structure parameters of sandstone at various temperatures.

\begin{tabular}{lcc}
\hline Temperature $\left({ }^{\circ} \mathrm{C}\right)$ & Average pore size $(\mathrm{nm})$ & Porosity $(\%)$ \\
\hline 20 & 38 & 3.7 \\
100 & 26 & 3.5 \\
200 & 48 & 4.2 \\
300 & 81 & 5.3 \\
400 & 176 & 8.6 \\
500 & 284 & 13.5 \\
600 & 372 & 18.2 \\
700 & 449 & 24.8 \\
\hline
\end{tabular}

4.3. Weakening Mechanism of Sandstone at Real-Time High Temperature. According to the variation of fracture toughness, fractal dimension, and surface morphology of sandstone with temperature, the weakening mechanism of sandstone at a real-time high temperature can be divided into 3 stages.

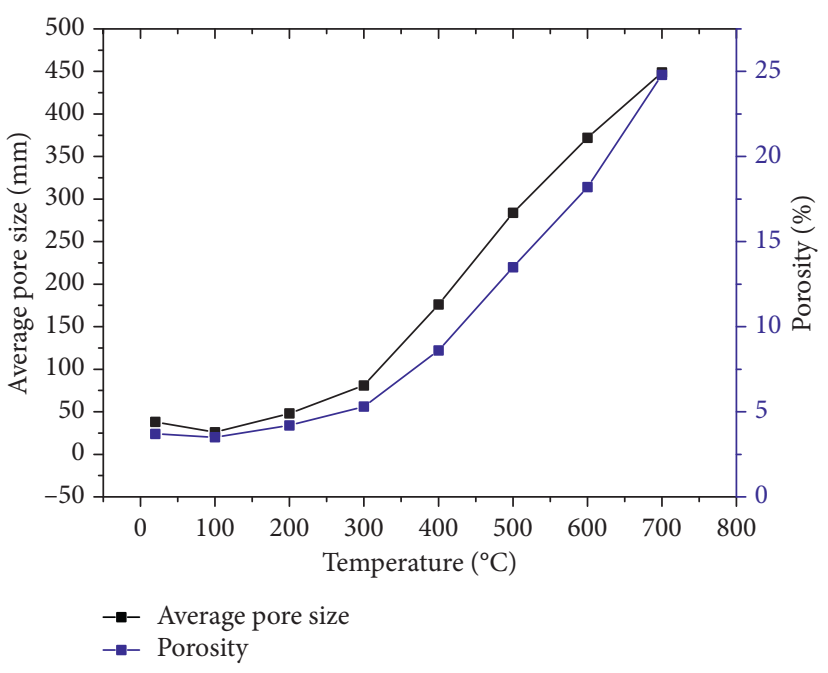

FIGURE 9: The relationship between average pore size and porosity of sandstone and temperature. 


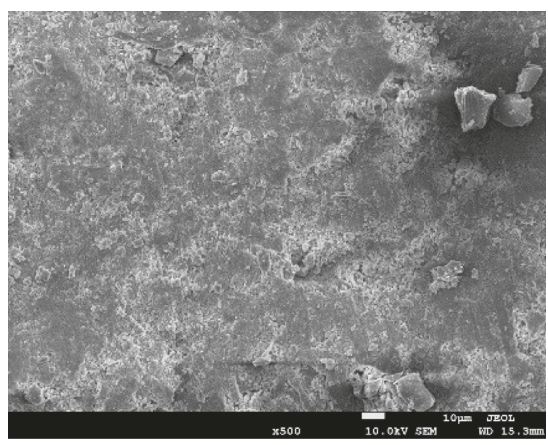

(a)

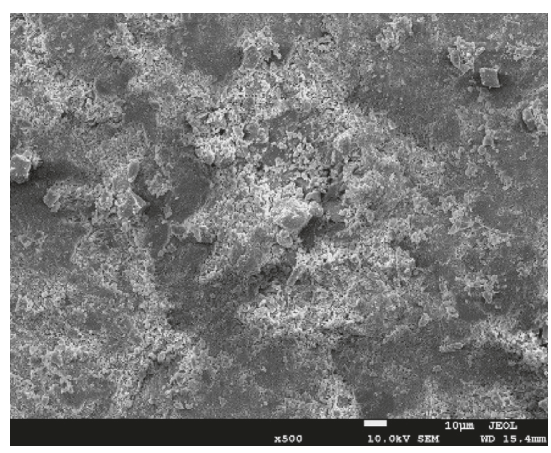

(c)

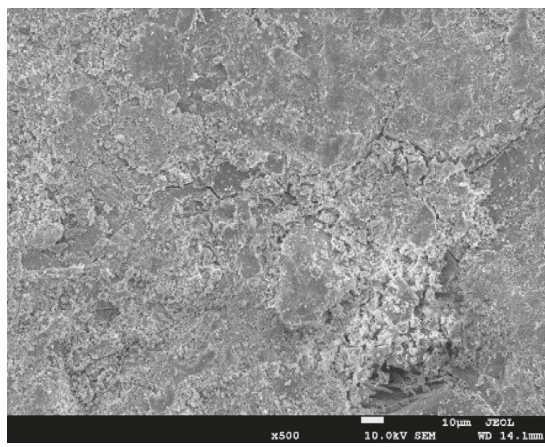

(e)

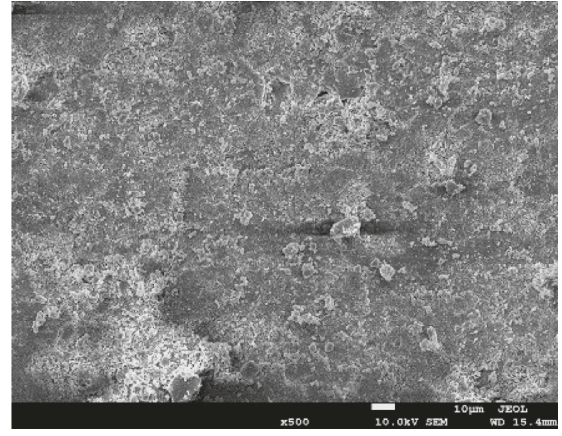

(b)

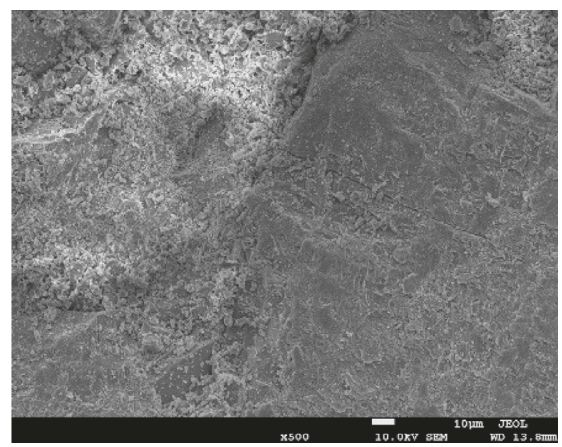

(d)

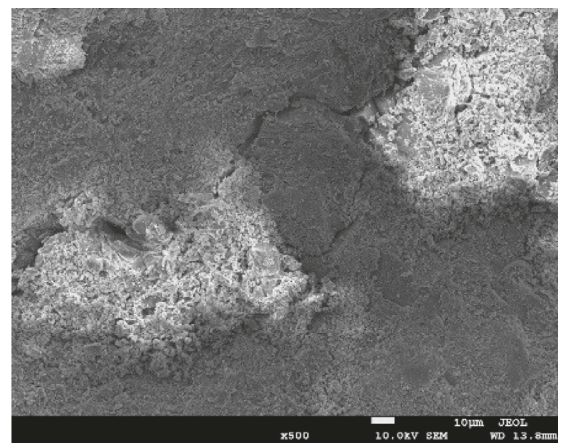

(f)

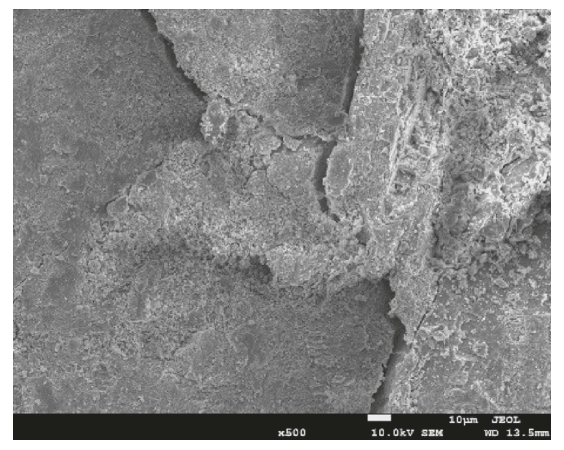

(g)

Figure 10: Fracture morphology of sandstone at different temperatures (SEM images): (a) $20^{\circ} \mathrm{C}$; (b) $100^{\circ} \mathrm{C}$; (c) $200^{\circ} \mathrm{C}$; (d) $300^{\circ} \mathrm{C}$; (e) $400^{\circ} \mathrm{C}$; (f) $500^{\circ} \mathrm{C} ;(\mathrm{g}) 600^{\circ} \mathrm{C}$

Stage I $\left(25^{\circ} \mathrm{C}-100^{\circ} \mathrm{C}\right)$ : at this stage, the fracture toughness of sandstone increases slightly with the increase in temperature. This is because the evaporation of free water and the closure of original pores and cracks occur at this temperature stage. According to the principle of effective stress, the evaporation of water leads to a decrease in pore pressure and an increase in effective stress, which causes the rock mass to be squeezed, and finally, the rock strength is increased. In addition, heating causes thermal stress inside the rock. When the temperature is relatively low, the thermal 
stress can only cause recoverable elastic deformation, which will not cause thermal cracking in the samples. Moreover, thermal expansion at relatively low temperatures will result in the closure of existing microcracks and inhibit the coalescence and interaction of existing cracks, which will lead to the enhancement of the overall structural strength of sandstone. Undoubtedly, the increase in rock strength will lead to an increase in resistance to intergranular and transgranular stress corrosion cracking and ultimately lead to an increase in fracture toughness. Since the transgranular fracture occurs mainly at this temperature stage, the deviation of transgranular fracture from the center line tends to be smaller compared with intergranular fracture, thus producing a relatively straight fracture trajectory. In summary, due to the volatilization of water and the closure of the primary pores, the fracture toughness of the specimens increased. However, since the thermal stress is small, the growth rate of the fracture toughness is relatively tiny.

Stage II $\left(100^{\circ} \mathrm{C}-400^{\circ} \mathrm{C}\right)$ : at this stage, the fracture toughness slowly decreases with the increase in temperature. On the contrary, as the temperature increases, the evaporation of water in the rock becomes more and more severe. Not only the bound water is fully evaporated but also the strong combined water and structural water are gradually lost. Dehydration has a direct effect on the structure of the rock. For example, a type I tensile crack occurs during the dehydration of serpentine (Jung et al. [54]). According to the results of MIP, the microstructures of sandstone change significantly at this stage compared with that at the first stage. Therefore, fracture toughness gradually decreases with the increase in temperature.

Stage III $\left(400^{\circ} \mathrm{C}-700^{\circ} \mathrm{C}\right)$ : there are three reasons for the weakening mechanism of specimens at this stage. The first reason is the decomposition of some minerals, the recrystallization of some minerals, and the formation of new minerals. In this way, the decomposition of minerals will produce a range of cracks with a broad distribution of dimensions (length and width), orientations, and shapes, which will result in a higher porosity and fractal dimension. Besides, according to the study of Yu et al. [55] and Liu et al. [56], crystal recrystallization facilitates crack propagation in the grain-boundary regions by enabling intergranular fracture and decohesion between mineral grains; secondly, rock is a heterogeneous body composed of different minerals, and the thermal expansion coefficients of each mineral are different at high temperature [57-60]. The inconsistency of expansion and deformation of mineral grains under relatively high temperature will cause high thermal stress in the mineral structure. The maximum thermal stress often occurs at the junction or boundary of mineral particles. If the stress reaches or exceeds the critical strength of rock, grainboundary microcracking may occur. According to the results of Feng et al. [17], thermal cracking will occur at $400^{\circ} \mathrm{C}$; thirdly, quartz in sandstone will transit from the $\alpha$ phase to $\beta$ phase (Grimm and Dorner [61]) at $573^{\circ} \mathrm{C}$. In the quartz lattice structure, two $\mathrm{Si}-\mathrm{O}$ tetrahedra are connected at an angle of $150^{\circ}$. When the quartz sand is heated to $573^{\circ} \mathrm{C}$, the two $\mathrm{Si}-\mathrm{O}$ tetrahedra in the crystal structure are connected at $180^{\circ}$. Due to the $\alpha-\beta$ phase transformation of quartz, the volume of quartz changes drastically, resulting in an increase in internal microcracks, which ultimately leads to changes in the microstructure and macroscopic physical and mechanical properties of the rock.

\section{Conclusion}

In this paper, the macroscopic and microscopic fracture behaviors of red sandstone under real-time high temperature are studied experimentally. The main conclusions are as follows:

(1) With the increase in temperature, the value of fracture toughness of sandstone first increases and then decreases; the value of fracture toughness reaches the maximum at $100^{\circ} \mathrm{C}$. According to the relationships between fracture toughness and temperature (i.e., curve slope), the variational trend of the curve can be divided into 3 stages: (1) the slow increase stage $\left(20^{\circ} \mathrm{C}-100^{\circ} \mathrm{C}\right)$. The curve slope at this stage is 0.0055 . (2) The slow descent stage $\left(100^{\circ} \mathrm{C}-\right.$ $400^{\circ} \mathrm{C}$ ). The curve slope at this stage is 0.0048 . (3) The rapid descending stage $\left(400^{\circ} \mathrm{C}-700^{\circ} \mathrm{C}\right)$, in which the slope of the curve is 0.0087 .

(2) The fractal dimension and the fracture deviation from the hypothetical fracture originating at the notch tip of sandstone specimens gradually increases with the increase in temperature. And, the values are smaller at relatively low temperatures $\left(20^{\circ} \mathrm{C}-400^{\circ} \mathrm{C}\right)$ but larger at relatively high temperatures $\left(400^{\circ} \mathrm{C}-700^{\circ} \mathrm{C}\right)$.

(3) The higher the temperature is, the more complex the chemical reactions occur in the crystals of sandstone. When the temperature of sandstone rises from room temperature to $700^{\circ} \mathrm{C}$, quartz decomposition and synthesis, the transition between quartz crystals, dehydration of feldspar, and synthesis and decomposition of feldspar will occur. And, the average pore size, total volume, and porosity of sandstone first decrease and then increase with the increase in temperature. When the temperature is between $100^{\circ} \mathrm{C}$ and $700^{\circ} \mathrm{C}$, these parameters of sandstone gradually increase with the increase in temperature, which indicates that the micropores gradually change to mesopores and macropores. On the whole, the variational trend of mesoparameters is basically consistent with that of fracture toughness.

(4) There are some differences in the fracture morphology of the specimens at real-time high temperatures, which have not been found in the specimens after treatment with high temperatures. Some cracks appear on the fracture surface at $400^{\circ} \mathrm{C}$ and the density, number, and aperture of the fractures increase with the increasing temperature. Some of the crystals in sandstone are molten under realtime high-temperature conditions, and the mechanical properties are similar to those of soft rock, so the sandstone tends to deform plastically. Plastic deformation can cause tearing cracks in the fracture surfaces of the specimen. 


\section{Data Availability}

The data used to support the findings of this study are available from the corresponding author upon request.

\section{Conflicts of Interest}

The authors declare that they have no conflicts of interest.

\section{Acknowledgments}

This paper was supported by the Natural Science Funds for Young Scholar (51504220) and National Natural Science Foundation of China (Grant no. 51574173), which the authors thank a lot.

\section{References}

[1] J.-p. Zuo, H.-p. Xie, F. Dai, and Y. Ju, “Three-point bending test investigation of the fracture behavior of siltstone after thermal treatment," International Journal of Rock Mechanics and Mining Sciences, vol. 70, pp. 133-143, 2014.

[2] J. Zuo, X. Wei, J. Pei, and X. Zhao, "Investigation of mesofailure behaviors of Jinping marble using SEM with bending loading system," Journal of Rock Mechanics and Geotechnical Engineering, vol. 7, no. 5, pp. 593-599, 2015.

[3] J.-P. Zuo, X.-S. Wang, D.-Q. Mao, C.-L. Wang, and G.-h. Jiang, "T-M coupled effects on cracking behaviors and reliability analysis of double-notched crustal rocks," Engineering Fracture Mechanics, vol. 158, pp. 106-115, 2016.

[4] J.-P. Zuo, J.-T. Wang, Y.-J. Sun, Y. Chen, G.-H. Jiang, and Y.-H. Li, "Effects of thermal treatment on fracture characteristics of granite from Beishan, a possible high-level radioactive waste disposal site in China," Engineering Fracture Mechanics, vol. 182, pp. 425-437, 2017.

[5] S. Shao, P. G. Ranjith, P. L. P. Wasantha, and B. K. Chen, "Experimental and numerical studies on the mechanical behaviour of Australian Strathbogie granite at high temperatures: an application to geothermal energy," Geothermics, vol. 54, pp. 96-108, 2015.

[6] H. Zhao, X. Wang, and Z. Liu, "Experimental investigation of hydraulic sand fracturing on fracture propagation under the influence of coal macrolithotypes in Hancheng block, China," Journal of Petroleum Science and Engineering, vol. 175, pp. 60-71, 2019.

[7] J. Rutqvist, "The geomechanics of $\mathrm{CO}_{2}$ storage in deep sedimentary formations," Geotechnical and Geological Engineering, vol. 30, no. 3, pp. 525-551, 2012.

[8] X. Li and L. Weng, "Numerical investigation on fracturing behaviors of deep-buried opening under dynamic disturbance," Tunnelling and Underground Space Technology, vol. 54, pp. 61-72, 2016.

[9] B. Mahanta, T. N. Singh, and P. G. Ranjith, "Influence of thermal treatment on mode I fracture toughness of certain Indian rocks," Engineering Geology, vol. 210, pp. 103-114, 2016.

[10] B. Mahanta, N. Sirdesai, T. N. Singh, and P. G. Ranjith, "Experimental study of strain rate sensitivity to fracture toughness of rock using flattened Brazilian disc," Procedia Engineering, vol. 191, pp. 256-262, 2017.

[11] B. Mahanta, A. Tripathy, V. Vishal, T. N. Singh, and P. G. Ranjith, "Effects of strain rate on fracture toughness and energy release rate of gas shales," Engineering Geology, vol. 218, pp. 39-49, 2017.
[12] N. N. Sirdesai, B. Mahanta, P. G. Ranjith, and T. N. Singh, "Effects of thermal treatment on physico-morphological properties of Indian fine-grained sandstone," Bulletin of Engineering Geology and the Environment, vol. 78, no. 2, pp. 883-897, 2019.

[13] M. Tao, Y. Yechao, C. Jie, and H. Yaoqing, "Investigation on the permeability evolution of gypsum interlayer under high temperature and triaxial pressure," Rock Mechanics and Rock Engineering, vol. 50, no. 8, pp. 2059-2069, 2017.

[14] S.-Q. Yang, H.-W. Jing, Y.-H. Huang, P. G. Ranjith, and Y.-Y. Jiao, "Fracture mechanical behavior of red sandstone containing a single fissure and two parallel fissures after exposure to different high temperature treatments," Journal of Structural Geology, vol. 69, pp. 245-264, 2014.

[15] S.-Q. Yang, P. G. Ranjith, H.-W. Jing, W.-L. Tian, and Y. Ju, "An experimental investigation on thermal damage and failure mechanical behavior of granite after exposure to different high temperature treatments," Geothermics, vol. 65, pp. 180-197, 2017.

[16] S.-Q. Yang, W.-L. Tian, and Y.-H. Huang, "Failure mechanical behavior of pre-holed granite specimens after elevated temperature treatment by particle flow code," Geothermics, vol. 72, pp. 124-137, 2018.

[17] H. Xie and H. Sun, "The study on bivariate fractal interpolation functions and creation of fractal interpolated surfaces," Fractals, vol. 5, no. 4, pp. 625-634, 1997.

[18] J. Cai and B. Yu, "Prediction of maximum pore size of porous media based on fractal geometry," Fractals, vol. 18, no. 4, pp. 417-423, 2010.

[19] J. Cai, W. Wei, X. Hu, R. Liu, and J. Wang, "Fractal characterization of dynamic fracture network extension in porous media," Fractals, vol. 25, no. 2, Article ID 1750023, 2017.

[20] G. Feng, Y. Kang, T. Meng, Y.-q. Hu, and X.-h. Li, “The influence of temperature on mode I fracture toughness and fracture characteristics of sandstone," Rock Mechanics and Rock Engineering, vol. 50, no. 8, pp. 2007-2019, 2017.

[21] G. Feng, Y. Kang, F. Chen, Y.-w. Liu, and X.-c. Wang, "The influence of temperatures on mixed-mode (I + II) and modeII fracture toughness of sandstone," Engineering Fracture Mechanics, vol. 189, pp. 51-63, 2018.

[22] H. Tian, T. Kempka, S. Yu, and M. Ziegler, "Mechanical properties of sandstones exposed to high temperature," Rock Mechanics and Rock Engineering, vol. 49, no. 1, pp. 321-327, 2016.

[23] T. Meng, Y. Hu, R. Fang, J. Kok, Q. Fu, and G. Feng, "Study of fracture toughness and weakening mechanisms in gypsum interlayers in corrosive environments," Journal of Natural Gas Science and Engineering, vol. 26, pp. 356-366, 2015.

[24] T. Meng, Y. Hu, R. Fang, Q. Fu, and W. Yu, "Weakening mechanisms of gypsum interlayers from Yunying salt cavern subjected to a coupled thermo-hydro-chemical environment," Journal of Natural Gas Science and Engineering, vol. 30, pp. 77-89, 2016.

[25] T. Meng, Y. You, J. Chen, and Y. Hu, "Investigation on the permeability evolution of gypsum interlayer under high temperature and triaxial pressure," Rock Mechanics and Rock Engineering, vol. 50, no. 8, pp. 2059-2069, 2017.

[26] T. Meng, B. Xiankai, J. Zhao, and Y. Hu, "Study of mixed mode fracture toughness and fracture characteristic in gypsum rock under brine saturation," Environmental Earth Science, vol. 77, no. 10, pp. 6-17, 2018.

[27] T. Meng, M. Xiangxi, Z. Donghua, and Y. Hu, "Using microcomputed tomography and scanning electron microscopy to assess the morphological evolution and fractal dimension of a 
salt-gypsum rock subjected to a coupled thermal-hydrological-chemical environment," Marine and Petroleum Geology, vol. 98, pp. 316-334, 2018.

[28] T. Meng, D. Zhang, Y. Hu, X. Jianlin, S. Sufang, and L. Xiaoming, "Study of the deformation characteristics and fracture criterion of the mixed mode fracture toughness of gypsum interlayers from Yunying salt cavern under a confining pressure," Journal of Natural Gas Science and Engineering, vol. 58, pp. 1-14, 2018.

[29] T. Meng, R. Liu, X. Meng, D. Zhang, and Y. Hu, "Evolutions of permeability and pore structure of transversely isotropic calcareous sediments subjected to triaxial pressure and high temperature," Engineering Geology, vol. 253, pp. 27-35, 2019.

[30] Q. Z. Wang, X. M. Jia, S. Q. Kou, Z. X. Zhang, and P.-A. Lindqvist, "More accurate stress intensity factor derived by finite element analysis for the ISRM suggested rock fracture toughness specimen-CCNBD," International Journal of Rock Mechanics and Mining Sciences, vol. 40, no. 2, pp. 233-241, 2003.

[31] J. Tirosh, "Incipient fracture angle, fracture loci and critical stress for mixed mode loading," Engineering Fracture Mechanics, vol. 9, no. 3, pp. 607-616, 1977.

[32] F. Ouchterlony, A New Core Specimen for the Fracture Toughness Testing of Rock, Swedish Detonic Research Foundation Rep DS, Stockholm, Sweden, 1980.

[33] ISRM Testing Commission, "Suggested methods for determining the fracture toughness of rock," International Journal of Rock Mechanics and Mining Sciences \& Geomechanics Abstracts, vol. 25, no. 6, pp. 71-96, 1988.

[34] J. G. Donovan and M. G. Karfakis, "Adaptation of a simple wedge test for the rapid determination of mode I fracture toughness and the assessment of relative fracture resistance," International Journal of Rock Mechanics and Mining Sciences, vol. 41, no. 4, pp. 695-701, 2004.

[35] M. R. M. Aliha, M. R. Ayatollahi, and R. Pakzad, "Brittle fracture analysis using a ring-shape specimen containing two angled cracks," International Journal of Fracture, vol. 153, no. 1, pp. 63-68, 2008.

[36] F. Ouchterlony, "Extension of the compliance and stress intensity formulas for the single edge crack round bar in bending," ASTM STP, vol. 745, pp. 237-256, 1981.

[37] A. R. Ingraffea, "Mixed-mode fracture initiation in Indiana limestone and Westerly granite," in Proceedings of the 22nd US Symposium on Rock Mechanics (USRMS), Cambridge, Massachusetts, June 1981.

[38] C. Wang, Z. M. Zhu, and H. J. Liu, "On the I-II mixed mode fracture of granite using four-point bend specimen," Fatigue \& Fracture of Engineering Materials \& Structures, vol. 39, no. 10, pp. 1193-1203, 2016.

[39] L. M. Barker, "A simplified method for measuring plane strain fracture toughness," Engineering Fracture Mechanics, vol. 9, no. 2, pp. 361-369, 1977.

[40] C. Atkinson, R. E. Smelser, and J. Sanchez, "Combined mode fracture via the cracked Brazilian disk test," International Journal of Fracture, vol. 18, no. 4, pp. 279-291, 1982.

[41] R. J. Fowell and J. F. Chen, "The third chevron-notched rock fracture specimen-the cracked chevron-notched Brazilian disc," in Proceedings of the 31st US Rock Mechanics Symposium, pp. 295-302, Balkema, Golden, CO, USA, June 1990.

[42] M. R. M. Aliha, G. R. Hosseinpour, and M. R. Ayatollahi, "Application of cracked triangular specimen subjected to three-point bending for investigating fracture behavior of rock materials," Rock Mechanics and Rock Engineering, vol. 46, no. 5, pp. 1023-1034, 2013.
[43] ISRM Testing Commission, "Suggested method for determining mode I fracture toughness using cracked chevron notched Brazilian disc (CCNBD) specimens," International Journal of Rock Mechanics and Mining Sciences \& Geomechanics Abstracts, vol. 32, no. 7, pp. 57-64, 1995.

[44] L. Tutluoglu and C. Keles, "Mode I fracture toughness determination with straight notched disk bending method," International Journal of Rock Mechanics and Mining Sciences, vol. 48, no. 8, pp. 1248-1261, 2011.

[45] M. D. Kuruppu, Y. Obara, M. R. Ayatollahi, K. P. Chong, and T. Funatsu, "ISRM-suggested method for determining the mode I static fracture toughness using semi-circular bend specimen," Rock Mechanics and Rock Engineering, vol. 47, no. 1, pp. 267-274, 2014.

[46] M. Kataoka, Y. Obara, and M. Kuruppu, "Estimation of fracture toughness of anisotropic rocks by semi-circular bend (SCB) tests under water vapor pressure," Rock Mechanics and Rock Engineering, vol. 48, no. 4, pp. 1353-1367, 2015.

[47] N. A. Al-Shayea, K. Khan, and S. N. Abduljauwad, "Effects of confining pressure and temperature on mixed-mode (I-II) fracture toughness of a limestone rock," International Journal of Rock Mechanics and Mining Sciences, vol. 37, no. 4, pp. 629-643, 2000.

[48] B. Xiankai, T. Meng, and Z. Jinchang, "Study of mixed mode fracture toughness and fracture trajectories in gypsum interlayers in corrosive environment," Royal Society Open Science, vol. 5, no. 1, p. 171374, 2018.

[49] X. Liu, Z. Qu, T. Guo, D. Wang, Q. Tian, and W. Lv, “A new chart of hydraulic fracture height prediction based on fluidsolid coupling equations and rock fracture mechanics," Royal Society Open Science, vol. 5, no. 10, p. 180600, 2018.

[50] M. D. Kuruppu and K. P. Chong, "Fracture toughness testing of brittle materials using semi-circular bend (SCB) specimen," Engineering Fracture Mechanics, vol. 91, pp. 133-150, 2012.

[51] R. Liu, B. Li, and Y. Jiang, "A fractal model based on a new governing equation of fluid flow in fractures for characterizing hydraulic properties of rock fracture networks," Computers and Geotechnics, vol. 75, pp. 57-68, 2016.

[52] R. Liu, L. Yu, Y. Jiang, Y. Wang, and B. Li, "Recent developments on relationships between the equivalent permeability and fractal dimension of two-dimensional rock fracture networks," Journal of Natural Gas Science and Engineering, vol. 45, pp. 771-785, 2017.

[53] R. Liu, B. Li, Y. Jiang, and L. Yu, "A numerical approach for assessing effects of shear on equivalent permeability and nonlinear flow characteristics of 2-D fracture networks," Advances in Water Resources, vol. 111, pp. 289-300, 2018.

[54] H. Jung, I. I. H. W. Green, and L. F. Dobrzhinetskaya, "Intermediate-depth earthquake faulting by dehydration embitterment with negative volume change," Nature, vol. 428, no. 1, pp. 545-549, 2004.

[55] W. D. Yu, W. G. Liang, Y. R. Li, and Y. M. Yu, "The mesomechanism study of gypsum rock weakening in brine solutions," Bulletin of Engineering Geology and the Environment, vol. 75, no. 1, pp. 359-367, 2016.

[56] W. Liu, Z. Zhang, J. Chen et al., "Physical simulation of construction and control of two butted-well horizontal cavern energy storage using large molded rock salt specimens," Energy, vol. 185, pp. 682-694, 2019.

[57] F. Wu, J. Chen, and Q. Zou, "A nonlinear creep damage model for salt rock," International Journal of Damage Mechanics, vol. 28, no. 5, pp. 758-771, 2019. 
[58] J. Fan, J. Chen, D. Jiang et al., "A stress model reflecting the effect of the friction angle on rockbursts in coal mines," Geomechanics and Engineering, vol. 18, no. 1, pp. 21-27, 2019.

[59] C. Zhao, Y. m. Zhou, C. f. Zhao, and C. Bao, "Cracking processes and coalescence modes in rock-like specimens with two parallel pre-existing cracks," Rock Mechanics and Rock Engineering, vol. 51, no. 11, pp. 3377-3393, 2018.

[60] C. Zhao, J. Niu, Q. Zhang, C. Zhao, and Y. Zhou, "Failure characteristics of rock-like materials with single flaws under uniaxial compression," Bulletin of Engineering Geology and the Environment, vol. 78, no. 1, pp. 593-603, 2019.

[61] H. Grimm and B. Dorner, "On the mechanism of the $\alpha-\beta$ phase transformation of quartz," Journal of Physics and Chemistry of Solids, vol. 36, no. 5, pp. 407-413, 1975. 


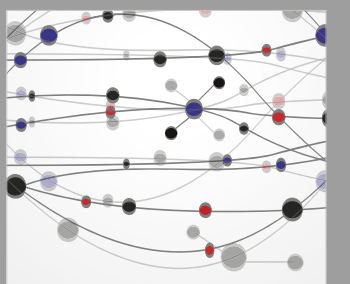

The Scientific World Journal
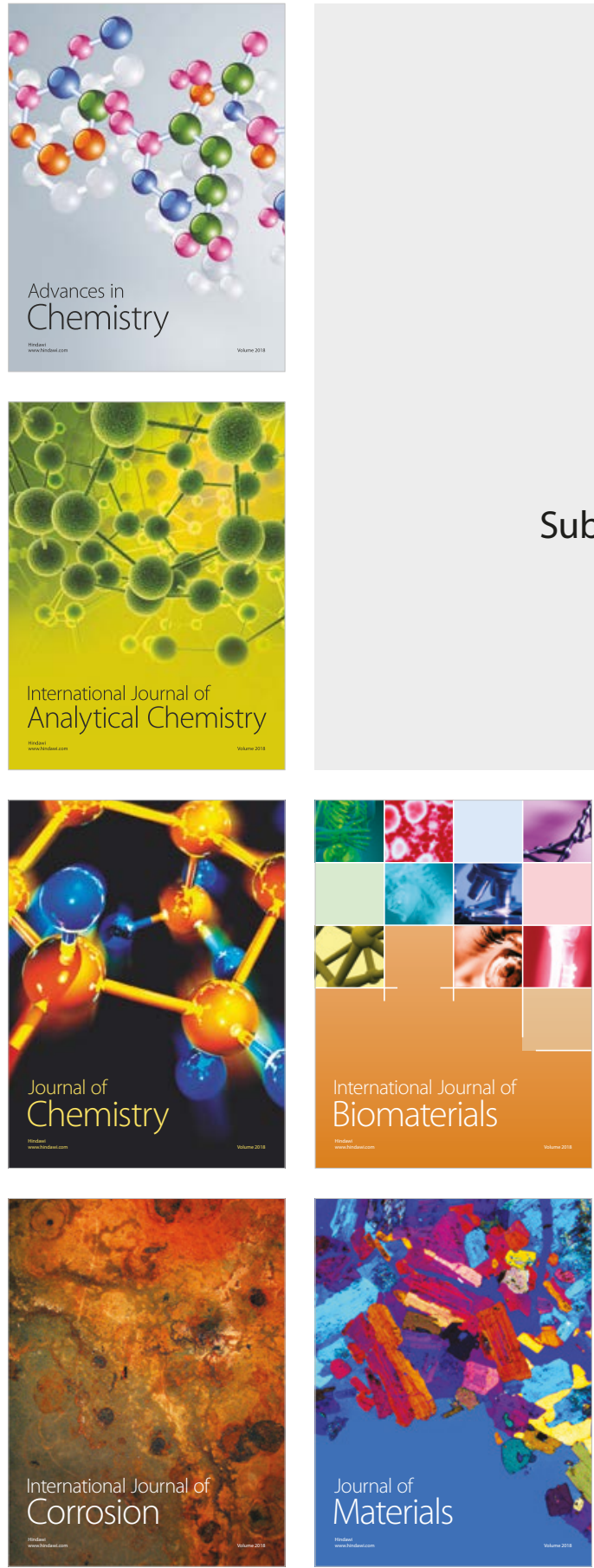

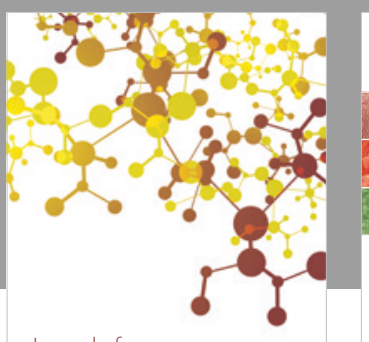

Journal of

Applied Chemistry
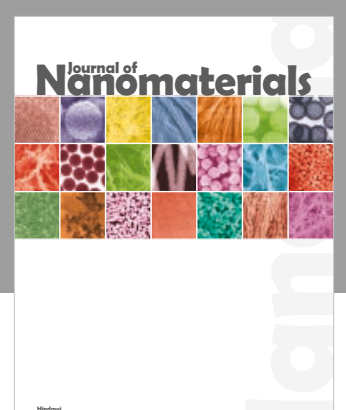

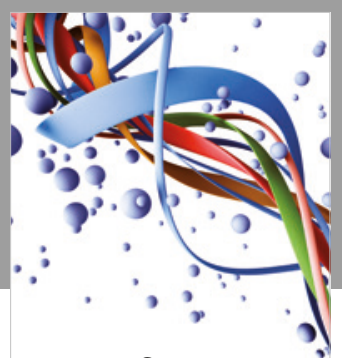

Scientifica

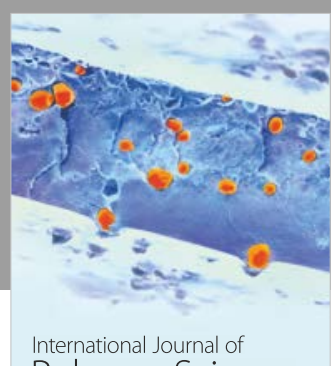

Polymer Science

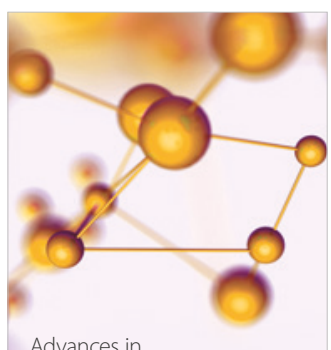

Physical Chemistry
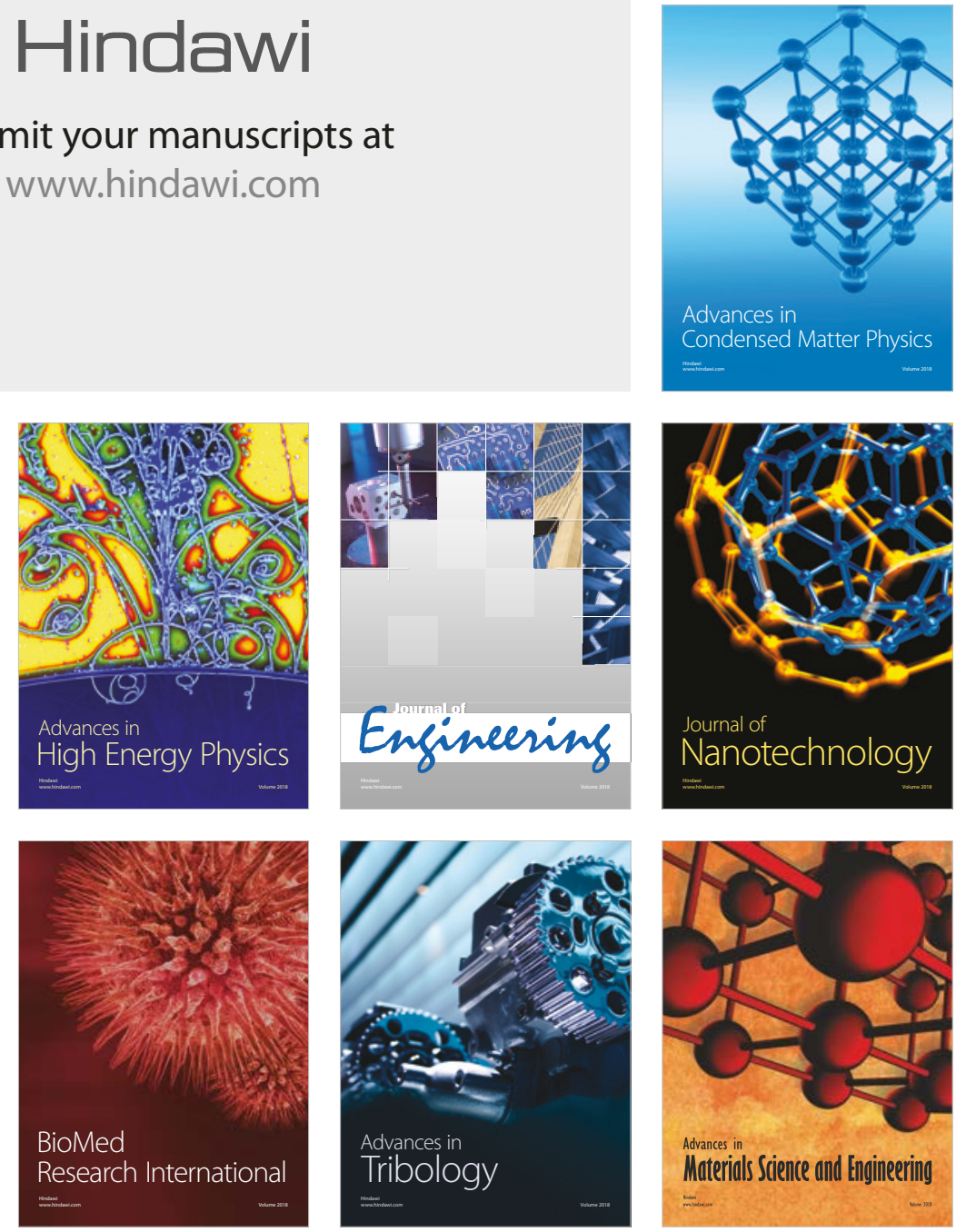